\title{
Phylogenetic study and association between prominent genotype and haplotype of KISS1 gene with FSH level in Idonesian native goat breeds
}

\author{
A. Febriana ${ }^{1,2}$, S. Sutopo ${ }^{2, *}$, E. Kurnianto ${ }^{2}$ and W. Widiyanto ${ }^{2}$ \\ ${ }^{1}$ Permanent address: Indonesian Center for Livestock Training Batu (ICLT) \\ Ministry of Agriculture of Indonesia, Batu 65301 - Indonesia \\ ${ }^{2}$ Department of Animal Science, Faculty of Animal and Agricultural Science, \\ Diponegoro University, Tembalang Campus, Semarang 50275 - Indonesia \\ Corresponding Author: drsutopo36@gmail.com
}

Received September 03, 2021;Accepted October 08, 2021

\begin{abstract}
ABSTRAK
Penelitian ini bertujuan untuk mengidentifikasi struktur populasi dan ekspresi gen KISS1 yang berkaitan dengan sifat reproduksi menggunakan analisis level follicle stimulating hormone (FSH) dan sekuensing DNA gen KISS1. Sejumlah 23 ekor induk yang terdiri dari kambing Kacang (n=7), Kejobong $(n=8)$ and Senduro $(n=8)$ diidentifikasi genotipenya menggunakan metode sekuensing DNA, 16 ekor diantaranya diberi perlakuan sinkronisasi estrus untuk diamati level hormon FSH menggunakan metode ELISA. Software MEGA X digunakan untuk menganalisa sekuens DNA, sedangkan General Linier Model (GLM) dari SAS software untuk menganalisa hormon FSH. Pohon filogeni memperlihatkan kesamaan yang tinggi antara kambing lokal Indonesia dengan spesies lain yang menunjukkan bahwa gen KISS1 konservatif. Analisis hormon FSH menunjukan hasil yang berbeda secara signifikan antara kambing Kacang dan Kejobong dibandingkan Senduro $(\mathrm{P}=0.002)$, litter size (LS) 3 dibandingkan LS $1(\mathrm{P}=0.0175)$, selanjutnya haplotipe CAATGCGCAACGCT dan genotipe GA pada g.2459 G>A menunjukkan hormon FSH yang lebih tinggi dibandingkan haplotipe dan genotipe yang lain $(\mathrm{P}=0.0027 ; \mathrm{P}<0.0001)$ dan terkait dengan $\mathrm{LS}$ yang tinggi $(3.0 \pm 0.18)$. Waktu pengambilan sampel dan paritas tidak memberikan perbedaan yang signifikan terhadap hormon FSH. Penelitian ini menunjukkan bahwa haplotipe TCAATGCGCAACGT and genotipe GA pada g.2459 $\mathrm{G}>\mathrm{A}$ mempunyai asosiasi dengan sifat reproduksi.
\end{abstract}

Kata kunci : FSH, gen KISS1, haplotipe, kambing lokal Indonesia, pohon filogeni

\begin{abstract}
The aim of the current research was to analyze the population structure and expression of KISS1 gene associated with reproductive traits through Follicle Stimulating Hormone (FSH) level and DNA sequencing analysis based on KISS1 gene. Genotypes of 23 goat does consist of Kacang goats $(n=7)$, Kejobong goats $(\mathrm{n}=8)$ and Senduro goats $(\mathrm{n}=8)$ were investigated using DNA sequencing, 16 out of 23 samples were synchronized to examine their FSH level using ELISA method. The data were analyzed using MEGA X software for DNA sequences and General Linier Model (GLM) for FSH plasma level. The phylogenetic tree showed the high homology between Indonesian native goats with other species showing a gene conservatism. A significantly higher FSH plasma levels were obtained from Kacang
\end{abstract}


and Kejobong than Senduro goat $(\mathrm{P}=0.002)$, litter size (LS) 3 than LS 1 ( $\mathrm{P}=0.0175)$, further CAATGCGCAACGCT haplotype and GA genotype at g.2459 G>A have a higher FSH plasma than other haplotypes and genotypes $(\mathrm{P}=0.0027 ; \mathrm{P}<0.0001)$ and are associated with high LS $(3.0 \pm 0.18)$. Neither sample collection times nor parities have different significantly. The current trial indicated that CAATGCGCAACGCT haplotype and GA genotype at g.2459 G>A were correlated with reproductive traits.

Keywords : FSH, haplotype, Indonesian native goat, KISSI gene, phylogenetic tree

\section{INTRODUCTION}

Goats, unlike other livestock species, are adaptable animals that can survive in tropical, mountainous, and desert environments. Goats have spread widely due to their adaptability to a variety of environments and nutrition availability, small size, prolific, useful productivity for humans, and non-competitiveness with human food, and they contribute significantly, particularly in rural areas (Aziz, 2010; Guerrero et al., 2019).

In Indonesia, there are more than 19 million goats, with eight goat breeds officially confessed. In Indonesia, goat population has increased over the last five years (Ministry of Agriculture, 2020). This condition could indicate that goats could be an alternative source of red meat. Aziz (2010) stated, Indonesia is one of the 10 largest lamb production country in the world. This situation might represent the Indonesian preference on goat meat because most of goats were reared and consumed locally. Enhancing reproductive traits could be a way to increase the number of goat population.

Indigenous goat breeds are well adapted to agro-ecological conditions, helping to ensure goat farming's long-term viability in rural and harsh environments (Stella, 2018). Goats are traditionally bred in Indonesia for meat and dual -purpose production. In this study, three indigenous goat breeds were used. Kacang $(\mathrm{KC}), \mathrm{Ke}-$ jobong (KJ), and Senduro (SD) goat breeds were known for their reproductive traits. $\mathrm{KC}$ has a significant high litter size even when reared in a harsh environment and can be raised as a meat type; KJ, the does is prolific, has a short kidding interval, and can be raised as a meat type (Sodiq and Haryanto, 2007), while the litter size (LS) in $\mathrm{SD}$ is $1.83 \pm 0.69$ and perform as dual purpose (meat and dairy) type (Ciptadi et al., 2019). KJ is solely located in Central Java, whereas SD goats start to spread massively in Indonesia following $\mathrm{KC} . \mathrm{KC}$ is also known as Indonesian native goats (Batubara et al., 2006). Half of In- donesian goat population is existed in Java, therefore a study based on goat population in Java was expected to represent the entire goat population in Indonesia, particularly in term of specific reproductive traits.

So far, the genetic structure of important economic traits has been identified, but the number of causative genes in goats has been lower than in sheep and cattle (Amills et al., 2017). The phenotypic variations of goats were shaped by various artificial or natural factors such as migration of human, environmental changes and influences of socioeconomic. Further, the genomic variability of goats were constructed mostly by breeding orientation and artificial selection during domestication (Wang et al., 2016). Principally, the sustainable selection and advancement of a novel traits in an environmental shifting needs the genetic diversity (Mandal et al., 2020).

Reproduction is a critical function for the survival of the species, thus this function is governed by complex regulatory signals. The hypothalamic-pituitary-gonadal (HPG) axis regulates reproductive activity by modulating the secretion of inhibitory factors and pituitary gonadotropins by the hypothalamus. Gonadotropin activity in the gonad is mediated by peripheral blood circulation (Nagamalleswari et al., 2004). The HPG axis is divided into three regulatory signals: 1) hypothalamus: gonadotropin-releasing hormone $(\mathrm{GnRH})$; 2) pituitary: gonadotropin, luteinizing hormone (LH) and follicle stimulating hormone (FSH); and 3) gonads: sex steroid and peptides (Pinilla et al., 2012).

Follicle stimulating hormone (FSH) is a pituitary gonadotropin which have essential task in reproduction. The main roles of FSH in female are maturation and development in antral follicles, encourage the antrum formation in secondary follicles and organize a response for ovulation when the LH surge (Mahdavi and Dashab, 2017).

The present study was undertaken to analyze the population structure and to explore the 
relative expression of KISS1 gene associated with reproductive traits through FSH level and DNA sequencing analysis from different goat breeds, litter size, haplotypes and genotypes to describe its relationship with litter size at kidding based on KISS1 gene sequences of three Indonesian indigenous goat breeds compare to other species sequences. Therefore, as KISS1 gene plays an important role on reproduction, this study was carried out.

\section{MATERIALS AND METHODS}

\section{Ethical Clearance}

The protocol of the current research was under the standart rule of animal treatment as designated in the Republic of Indonesia's law, that is, number 41, 2014.

\section{Animals and Samples Collection}

A total of 23 heads of goat does from three Indonesian indigenous goat breeds, namely $\mathrm{KC}$ $(n=7), K J(n=8)$ and SD $(n=8)$ were utilized in the present study. The goats were healthy, unrelated and were not pregnant. They were selected randomly based on LS, age, multiparous ( $1^{\text {st }}$ to $5^{\text {th }}$ parities) and have phenotypic characteristic of each breed. These breeds represent different regions and altitudes, $\mathrm{KC}$ from Grobogan regency, KJ from Purbalingga regency, both are in Central Java while SD is from Lumajang regency East Java (Fig.1). The Grobogan, Purbalingga and Lumajang were located at $100 \mathrm{~m}, 113 \mathrm{~m}$ and $500 \mathrm{~m}$ height above mean sea level (AMSL) respectively. The goats were kept by the farmer under the homogenous environment.

\section{Genomic DNA Extraction}

A total of $3 \mathrm{ml}$ of blood samples were collected via the jugular vein in to sterile vacuum tubes with anticoagulant (EDTA). The blood samples were shifted to the laboratory using coolbox and freezed at $-20^{\circ} \mathrm{C}$ until the genomic DNA extraction. Thus, GeneJET Genomic DNA Purification Kit (Thermo Scientific, USA) was applied to extract the genomic DNA from the whole blood correspond the manufacturer's guidance. The evaluation of DNA quality was set up by electrophoresis using agarose gel (1\%) and Nanodrop spectrophotometer Uvidoc HD6 (UVItec Ltd., Cambridge, UK).

A clear single band on agarose (1\%) electrophoresis and the optical density (OD) 260/280 ratio ranged between 1.7 and 2.0 (according to the kit protocol) verifying a good quality of DNA extraction.

\section{PCR Amplification}

A $1061 \mathrm{bp}$ fragment of intron 1 KISS1 gene was amplified with a pair of primer (F: 5'GCTCAGTGGCCAGGAATCTG-3'; R: 5'GCTCATAGCAGGGCCTCAAA-3'). The primers were designed using the sequence of KISS1 gene of Capra hircus breed Jining Grey (GenBank Accession Number GU142847.1) and Primer3 Plus software. Polymerase Chain Reaction (PCR) was performed in $50 \mu 1$ volume containing $4 \mu \mathrm{l}$ DNA extraction (20-30 ng/ $\mu \mathrm{l}), 1 \mu \mathrm{l}$ for each primer $(10 \mathrm{pmol} / \mu \mathrm{l}), 19 \mu \mathrm{ddH} 2 \mathrm{O}$ and $25 \mu 1$ of MyTaq Red Mix Bioline (1st BASE) on MJ Mini Personal Thermal Cycler (Bio-Rad, USA). PCR cycling program contain of predenaturation at $95^{\circ} \mathrm{C}$ for $5 \mathrm{~min}$, followed by 35 cycles of denaturation at $94^{\circ} \mathrm{C}$ for $30 \mathrm{~s}$, annealing at $60^{\circ} \mathrm{C}$ for $30 \mathrm{~s}$, extension at $72{ }^{\circ} \mathrm{C}$ for $30 \mathrm{~s}$, and post extension at $72{ }^{\circ} \mathrm{C}$ for $7 \mathrm{~min}$. The amplicon was performed by electrophoresis in $2 \%$ agarose gel (Invitrogen, Life Technologies Co,

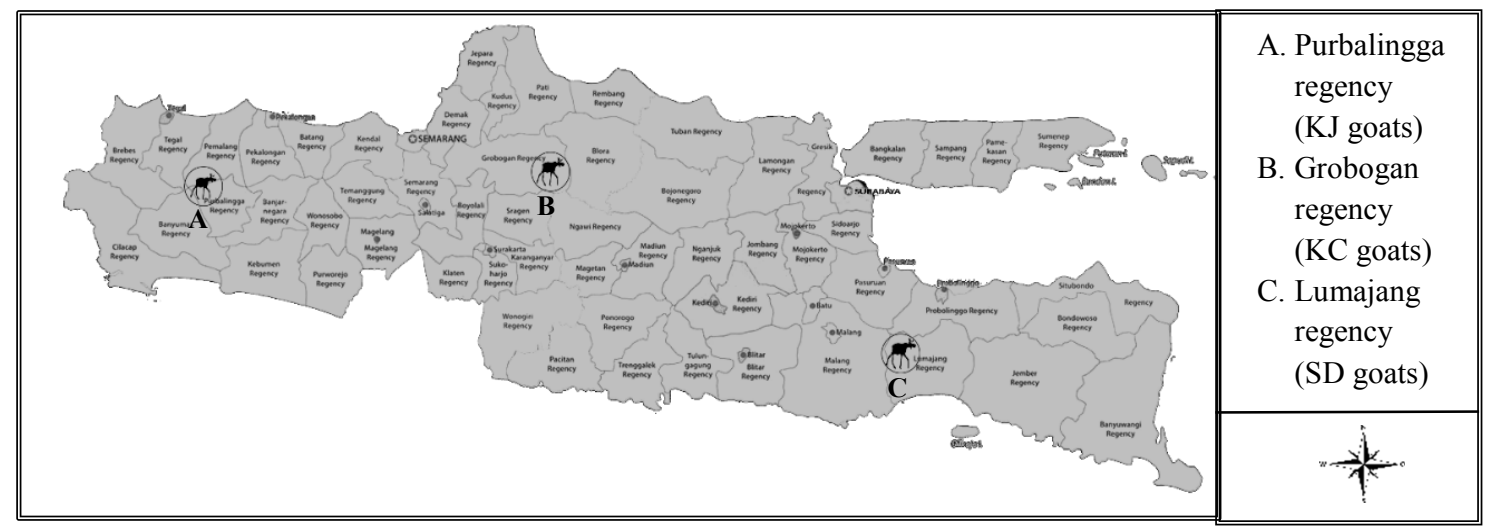

Figure 1. Distribution of sampling area in Java island, Indonesia 
$\mathrm{CA})$ at $100 \mathrm{~V}$ for $30 \mathrm{~min}$.

\section{DNA Sequencing and Analysis}

The amplicon of 23 goats reflecting three indigenous Indonesian goat breeds were sequenced both forward and reverse direction using commercial service (1st BASE). The goats were selected based on breeds, litter size, parity, age and goats which treated with estrus synchronization. The goat sequences were categorized into five groups, which are LS $1(\mathrm{KCl}, \mathrm{KClb}$, KJ1a, KJ1b, SD1a and SD1b), LS 2 (KJ2a, $\mathrm{KJ} 2 \mathrm{~b}, \mathrm{KJ} 2 \mathrm{c}, \mathrm{KJ} 2 \mathrm{a}, \mathrm{KJ} 2 \mathrm{~b}, \mathrm{SD} 2 \mathrm{a}, \mathrm{SD} 2 \mathrm{~b}, \mathrm{SD} 2 \mathrm{c}$ and SD2d), LS 3 (KC3a, KC3b, KJ3a, KJ3b, $\mathrm{KJ} 3 \mathrm{c}$ and SD3a ), LS 4 (KJ4a) and LS 5 (SD5a). Alignment of multiple-sequences were performed by software MEGA X 10.1 version to explore the variation of single nucleotide polymorphisms (SNPs).

\section{Estrus Synchronization, Blood Samples and Hormonal Assay (ELISA)}

Five goat does for each $\mathrm{KC}$ and $\mathrm{KJ}$ and six SD goat does with different LS were treated with $0.30 \mathrm{mg}$ medroxyprogesterone acetate (MAP) intravaginal sponges for 14 days. The blood samples were collected five times $(0,3,6$, 9 and 12 hours) after the sponge removal. A total $3 \mathrm{ml}$ of blood samples were collected in plain and sterile vacutainer tubes. Then, the blood samples were centrifuged $(3000 \mathrm{rpm} / 5 \mathrm{~min})$ to obtain serum and stored at $-20^{\circ} \mathrm{C}$ in eppendorf tubes until assayed for FSH profile. FSH hormone levels was estimated using Goat Follicle Stimulating Hormone Kit (Bioassay Technology Laboratory Cat. No. E0006Go Shanghai, China) and counting using microplate reader (ZENIX320 , USA). The stand art curve ranged from $0.05 \mathrm{mlU} / \mathrm{ml}$ to $15 \mathrm{mlU} / \mathrm{ml}$ and the sensitivity is $0.028 \mathrm{mlU} / \mathrm{ml}$. The intra-assay coefficient of variance $(\mathrm{CV})$ and the inter-assay $\mathrm{CV}$ less than $8 \%$ and $10 \%$ respectively. The ELISA was performed as per kit guidance.

\section{Statistical Analysis}

Population Structure. The data were analyzed using MEGA $\mathrm{X}$ software to acquire the singleton variable, parsimony sites, genetic distance within and between goat breed and to form phylogenetic tree. The neighbor-joining method was used to build the phylogenetic tree. Different sequences of KISS1 gene from other vary species were acquired from the NCBI GenBank database (https://www.ncbi.nlm.nih.gov/) for phylogenetic analysis. The distance between sequence pairs were represented by the length of each pair of branches. The scale under the tree is indicating the nucleotide substitution number. The DnaSP software were used to calculate haplotype diversity, number of haplotypes, number of mutations, Fst and Tajima's D. The Arlequin software was utilized to obtain haplotype shares and haplotype frequencies.

Basic local alignment search tool (BLAST) was used to detect the homology sequences in diverse breeds or species. Six different KISS1 gene sequences from different species/breed have been selected from the GenBank with accession number listed below (Tabel 1).

Follicle stimulating hormone (FSH) level. The data were analyzed using General Linier Model (GLM) of SAS Software. Fixed model used for FSH :

$$
\begin{gathered}
y_{i j k l m n}=\mu+g_{i}+b_{j}+c_{k}+l_{l}+p_{m}+ \\
h_{n}+e_{i j k l m n}
\end{gathered}
$$

where $\mathrm{y}_{\mathrm{ijklmn}}$ is FSH plasma level measured for each samples, $\mu$ is the overall mean, $g_{i}$ is the fixed effect of $i$ th genotype ( $i=1,2,3), b_{j}$ is the fixed effect of $j$ th breed $(\mathrm{j}=1,2,3)$, $\mathrm{c}_{\mathrm{k}}$ is the fixed effect of $k$ th collection time $(\mathrm{k}=1,2,3,4,5)$, $l_{1}$ is the fixed of $l$ th litter size $(1=1,2,3,4,5), p_{m}$ is the fixed of $m$ th parities $(\mathrm{m}=1,2,3), \mathrm{h}_{\mathrm{n}}$ is the fixed of $n$th haplotypes $(n=1,2, \ldots, 14)$ and $\mathrm{e}_{\mathrm{ij}}$ is a random error of each observation. When $\mathrm{P}$ $<0.05$ it was verify significant statistically. In this study, multiple comparisons of the means were

Table 1. KISS1 gene sequences of different species from the GenBank used to develope the phylogenetic tree

\begin{tabular}{llc}
\hline \multicolumn{1}{c}{ Species } & \multicolumn{1}{c}{ Accession number } & Similarity (\%) \\
\hline Jining Grey & GU. 142847.1 & 99.69 \\
Ovis aries & KP835797.1 & 99.47 \\
Capra hircus & KR065750.1 & 97.66 \\
Bos indicus & XM_019976949.1 & 87.91 \\
Sus scrofa & AB466320.1 & 81.14 \\
Homo sapiens & NG_032151.1 & 67.38 \\
\hline
\end{tabular}


tested using Tukey-Kramer with significant level of $5 \%$.

\section{RESULTS AND DISCUSSION}

\section{Nucleotide Sequence Identity and Phylogenet- ic Tree of KISS1 Gene}

The OD ratio 260/280 ranged from 1.7 to 2.0 , indicating that extracted DNA was not contaminated and in good quality. Psifidi et al. (2015) confirming that the standart of OD ratio $260 / 280$ is $\geq 1.8$, depend on the extraction kit used. A higher ratio number showed higher purity of DNA extract. Therefore, the extracted DNA could be sequenced both forward and reverse directions immediately in this study.

BLAST from NCBI were used to find the degree of similarity between chosen sequences (http:// https://blast.ncbi.nlm.nih.gov/Blast.cgi). Three species/breed that have the highest similarity are Jining grey goats from China (GU. 142847.1), Ovis aries (KP835797.1) and Capra hircus (KR065750.1) for 99.69\%, 99.47\% and $97.66 \%$ respectively (Table 1 ). The homologous sequences from other species/breed were obtained from NCBI GenBank database. The closely related sequences could be indicated from the similarity at nucleotide level. The DNA sequences similarity interprets that the function and structure of regulatory elements or protein products of gene expression is similar (Mahdavi and Dashab, 2017) and high conservatism gene in species (Zheng et al., 2018).

Homology of KISS1 gene with other species ranged between Homo sapiens (NG 032151.1) with $78.74 \%$ similarity to Capra hircus Jining Grey breed (99.69\%). Zheng et al. (2018) found the similar result in previous research on Jintang Black goat (JTG). The similarity between KC, $\mathrm{KJ}$, SD and JTG is $99.02 \%$. This output denoted that KISS1 gene is conserve in many species because of its significant role in reproduction.

The sequences analysis could be performed by aligning the gene sequences with specific role to determine the evolutionary correlation between unrecognized sequences and approved sequences (GenBank) to construct a phylogenetic tree, branching and discrepancy between species (Mahdavi and Dashab, 2017). The analysis of nucleotide sequences using MEGA X software between the indigenous goats represented 18 variable sites which include five singleton sites, 13 parsimony sites and 14 haplotypes.

Diversity in entire population is 1.18. Mean- while, the mean distance is 1.39 that calculated from all DNA sequences which show the average of entire sequence pairs and the amount of base changes at each site. The distance within group is calculated by the average number of base changes between all sequences within the group. The disparity was enumerated to be $0.0046,0.0047$ and 0.0051 in $\mathrm{KC}, \mathrm{KJ}$ and SD respectively, while the distance between groups are shown in Table 2. The previous experiment found that the genetic distance based on BMP15 gene was counted to be 0.4 in cows, 1.0 in pig, 4.1 in sheep and 2.1 in goats (Mahdavi and Dashab, 2017). This condition indicated that nucleotide substitutions in goat species of BMP15 gene higher than KISS1 gene caused by evolution correlated with gene expression mechanisms, thus this condition showed that KISS1 gene more conserve than BMP15 gene.

The common haplotype in three Indonesian

Table 2. The mean genetic distance between Indonesian goat breeds using the number of base pair in KISS1 gene

\begin{tabular}{cccc}
\hline Goat & KC & KJ & SD \\
\hline KC & & 0.021 & 0.082 \\
KJ & 0.0047 & & 0.195 \\
SD & 0.0053 & 0.0061 & \\
\hline
\end{tabular}

Values above the diagonal are Fst and genetic distance value are under diagonal; KC : Kacang goats; KJ : Kejobong goats; SD : Senduro goats

goat breeds is CATAGCGGGGCACT (H1) and the haplotype frequencies are $0.143,0.5$ and 0.125 for $\mathrm{KC}, \mathrm{KJ}$ and SD respectively. In addition, overall haplotype CATAGCGGGGCACT (H1) frequency in the entire population is $26.1 \%$ and the haplotype diversity is 0.913 .

The average pairwise fixation index (Fst) value is $0.021(\mathrm{KC}$ and $\mathrm{KJ})$ and $0.082(\mathrm{KC}$ and $\mathrm{SD})$. This value is lower than previous values resulted in South-east Asia. Barker et al. (2001) reported that Fst value between South-east Asian goat is 0.14 . In contrary, the Fst value between $\mathrm{KJ}$ and $\mathrm{SD}$ is 0.195 . This data showed that genetic structure differentiation between $\mathrm{KJ}$ and $\mathrm{SD}$ is higher than $\mathrm{KC}$ to $\mathrm{KJ}$ and $\mathrm{SD}$, thus indicated that $\mathrm{KC}$ is an ancestor for $\mathrm{KJ}$ and SD. In accordance, Lestari et al. (2018) reported that KJ is a crossbred of KC goat and Etawah Grade (EG). Further research needs to investigate the phylogenetic relationship between $\mathrm{KC}$ and SD. 
Table 3. The mean distance between species using the number of base pair in KISS1 gene

\begin{tabular}{|c|c|c|c|c|c|c|c|c|c|}
\hline Species & $\begin{array}{c}\text { Jining } \\
\text { grey }\end{array}$ & $\mathrm{KC}$ & $\mathrm{KJ}$ & SD & $\begin{array}{l}\text { Capra } \\
\text { hircus } \\
\end{array}$ & $\begin{array}{l}\text { Ovis } \\
\text { aries }\end{array}$ & $\begin{array}{c}\text { Bos } \\
\text { indicus }\end{array}$ & $\begin{array}{c}\text { Homo } \\
\text { sapiens }\end{array}$ & $\begin{array}{c}\text { Sus } \\
\text { scrofa } \\
\end{array}$ \\
\hline \multicolumn{10}{|l|}{ Jining grey } \\
\hline $\mathrm{KC}$ & 0.003 & & & & & & & & \\
\hline KJ & 0.004 & 0.005 & & & & & & & \\
\hline $\mathrm{SD}$ & 0.003 & 0.005 & 0.006 & & & & & & \\
\hline Capra hircus & 2.261 & 2.294 & 2.282 & 2.293 & & & & & \\
\hline Ovis aries & 4.325 & 4.312 & 4.285 & 4.296 & 2.701 & & & & \\
\hline Homo sapiens & 3.427 & 3.342 & 3.404 & 3.387 & 3.049 & 6.393 & & & \\
\hline Bos indicus & 3.850 & 3.843 & 3.896 & 3.819 & 2.781 & 4.259 & 2.840 & & \\
\hline Sus scrofa & 4.411 & 4.437 & 4.467 & 4.455 & 3.950 & 4.606 & 3.106 & 4.529 & \\
\hline
\end{tabular}

The nucleotide frequency of thymine/uracil, cytosine, adenine and guanine is $23.3 \%, 27.7 \%$, $23.5 \%$ and $25.5 \%$ respectively. Nucleotide substitution rate between species/groups were estimated using Tamura-Nei model in MEGA X software (Table 3). These results denote the opportunity for replacement of each nucleotide with another one. The distance was estimated using the amount of bases and pair comparison method. The distance between Homo sapiens and Ovis aries were the maximum (6.393), while the closest distance was between Indonesian goats and Jining grey goats. This data could be confirmed with the phylogenetic tree, where $\mathrm{Ho}$ - mo sapiens and Ovis aries found in different branch. Furthermore, Indonesian native goats and Jining grey goat were located in the same node.

Adaptation is in reaction to selection of production methods and connected with local environmental situation. The alpine (Capra ibex) ibex and Spanish (Capra pyrenaica) have shown that both species were introgressed by domestic goat based on major histocompatibility complex (MHC) genes (Stella et al., 2018). Phylogenetic tree of domestic and wild goat species based on Y-chromosome, nuclear marker or mitochondrial are discrepant (Amills et al., 2017). The incongruous between nucleus and mtDNA phylogenies

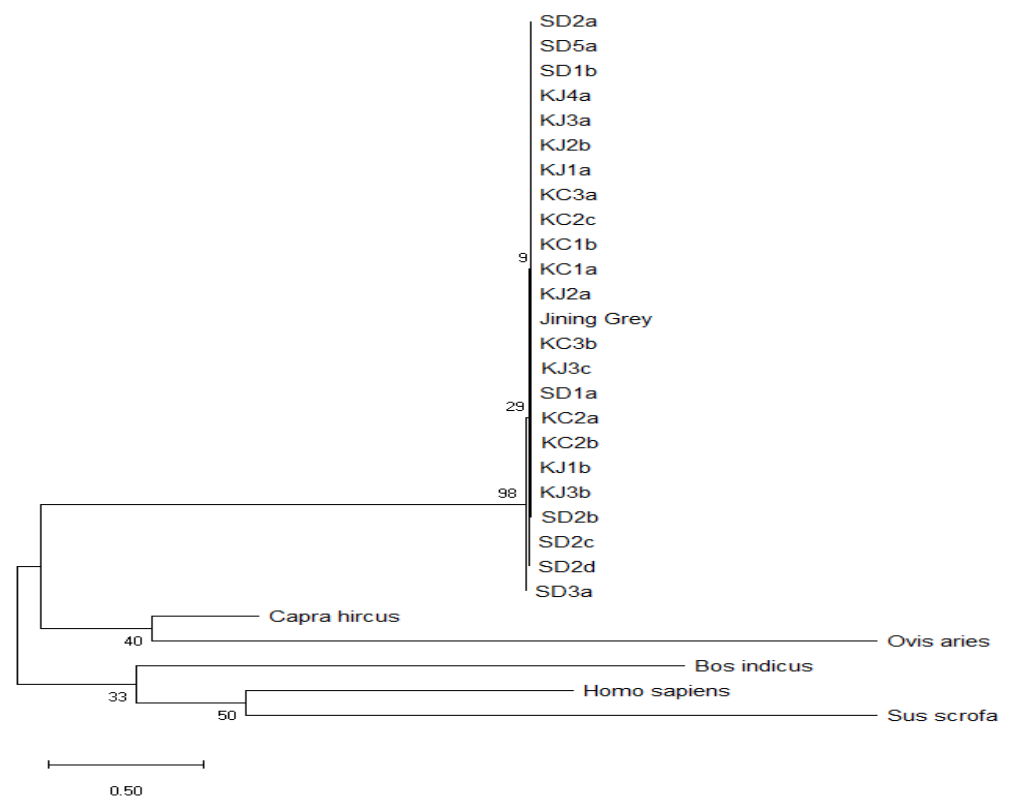

Figure 2. Phylogenetic tree of KISS1 gene of different species 


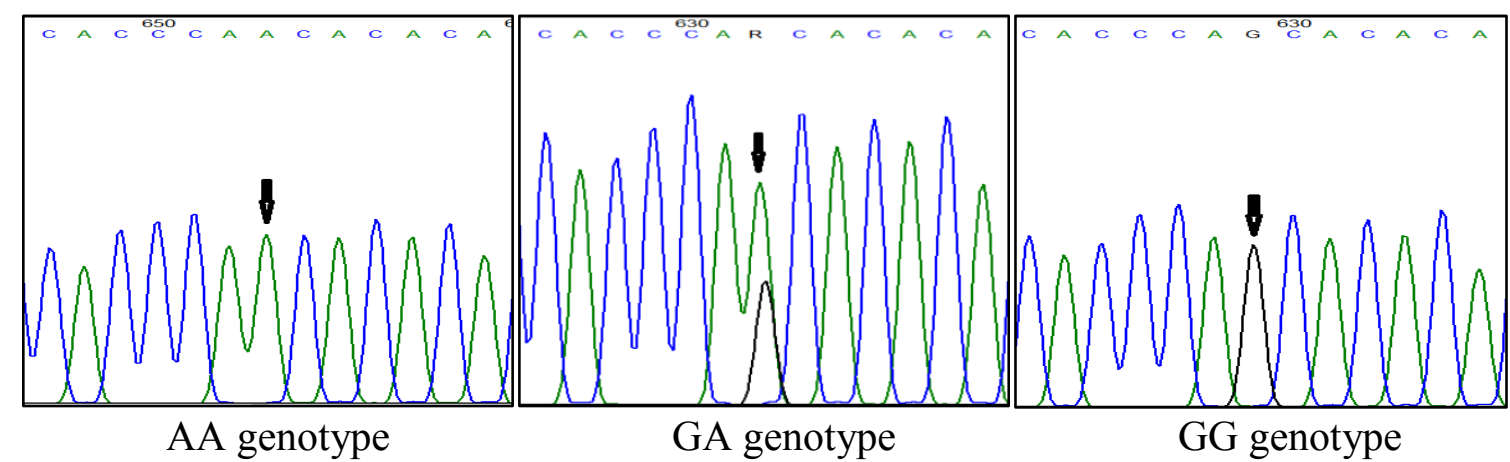

Figure 3. Genotypes of g.2459G $>$ A

were caused by interspecific hybridization, rather than lineage sorting or paralogs (Ropiquet and Hassanin, 2006).

BLAST was used to identify similarity between DNA sequences. Other homolog species were used to align the nucleotide sequences of KISS1 gene to illustrate the phylogenetic tree. The nucleotide sequence of Indonesian goat breeds were identical with Jining grey goats, Ovis aries and Bos indicus for 99.69\%, 99.20\% and $88.98 \%$ respectively (Fig. 2). This data also confirmed the Fst value in this study (Table 2). The similarity between goats, sheeps and cattle which are ruminants, shows that KISS1 gene may have equivalent function in ruminants.

The phylogenetic tree shows two main clades of the phylogenetic relationship of all sequences. The last nodes of the phylogenetic tree denote the current sequences of samples used, while the internal nodes pointed as suspect ancestor sequences. The nearest genetic relationship is between Indonesian native goats and Jining grey goats because it located in the same node. The other branch in the same clade with Indonesian goat breeds are Capra hircus and Ovis aries. Hereinafter the next clade consists of Bos indicus, Homo sapiens and Sus scrofa. The phylogenetic tree denoted a similarity and distance between species based on KISS1 gene. The phylogenetic tree from prior research (Zheng et al., 2018) showed similar clustering among various species which acquired in this study even the accession numbers of NCBI used are different.

\section{KISS1 Gene Expression and FSH Plasma Lev- el}

An estrus synchronization was used in the current research using progestagen intravaginal sponge. Wildeus (2000) reported that the previous research in different breeds such as Cashmere, Alpine, Boer, Saanen and Nubian revealed that the effectiveness of estrus synchronization using intravaginal sponges might represent significant differences led by distinct species, breeds, treatment management and mating sys-

Table 4. Means \pm SE of FSH (mIU/ml) on haplotype $(\mathrm{P}<0.0001)$

\begin{tabular}{ccc}
\hline & Haplotype Variations & FSH \\
\hline H9 & CAATGCGCAACGCT & $10.65 \pm 1.27^{\mathrm{a}}$ \\
H4 & TATTGCACAACGCT & $8.99 \pm 0.54^{\mathrm{b}}$ \\
H2 & CATAGCGCAACGCT & $4.77 \pm 0.49^{\mathrm{c}}$ \\
H8 & TATAGCGGGGCGCT & $2.72 \pm 0.14^{\mathrm{d}}$ \\
H10 & CATTGCGCAGTGCT & $1.97 \pm 0.08^{\mathrm{de}}$ \\
H1 & CATAGCGGGGCACT & $1.76 \pm 0.14^{\mathrm{de}}$ \\
H6 & CATTGCACAACGCT & $1.54 \pm 0.06^{\mathrm{de}}$ \\
H3 & TCTTGCGGGGTACT & $1.49 \pm 0.08^{\mathrm{de}}$ \\
H7 & TAATGCGCAACGTT & $1.48 \pm 0.12^{\mathrm{de}}$ \\
H13 & CATTCTGCAATGCA & $1.30 \pm 0.19^{\mathrm{e}}$ \\
H14 & CCTTCTGCAGTGCT & $1.21 \pm 0.09^{\mathrm{f}}$ \\
H11 & CATTGCACAGTGCT & $0.67 \pm 0.05^{\mathrm{g}}$ \\
H12 & CAATCCGCAATGCT & $0.66 \pm 0.05^{\mathrm{h}}$ \\
\hline
\end{tabular}


Table 5. Means $\pm \mathrm{SE}$ of FSH (mIU/ml) based on goat breeds, sample collection time, litter size, parity and genotype

\begin{tabular}{|c|c|c|c|}
\hline Specification & P Value & Category & Means \pm SE \\
\hline \multirow[t]{3}{*}{ Breed } & $\mathrm{P}=0.002$ & $\mathrm{KC}$ & $3.88 \pm 0.63^{\mathrm{a}}$ \\
\hline & & $\mathrm{KJ}$ & $3,73 \pm 0.75^{\mathrm{a}}$ \\
\hline & & SD & $1.49 \pm 0.19^{\mathrm{b}}$ \\
\hline \multirow{5}{*}{$\begin{array}{l}\text { Sample collection } \\
\text { time }\end{array}$} & $\mathrm{P}=0.9361$ & 0 hours & $2.48 \pm 0.59$ \\
\hline & & 3 hours & $2.88 \pm 0.74$ \\
\hline & & 6 hours & $2.89 \pm 0.73$ \\
\hline & & 9 hours & $2.97 \pm 0.74$ \\
\hline & & 12 hours & $3.45 \pm 0.99$ \\
\hline \multirow[t]{4}{*}{ Litter size } & $\mathrm{P}=0.0175$ & $1 \mathrm{kid}$ & $1.28 \pm 0.15^{b}$ \\
\hline & & 2 kids & $2.61 \pm 0.47^{\mathrm{ab}}$ \\
\hline & & 3 kids & $4.21 \pm 0.78^{\mathrm{a}}$ \\
\hline & & 5 kids & $3.77 \pm 0.32^{\mathrm{a}}$ \\
\hline \multirow[t]{3}{*}{ Parity } & $\mathrm{P}=0.0352$ & 1st parity & $3.77 \pm 0.32$ \\
\hline & & 2nd parity & $2.27 \pm 0.34$ \\
\hline & & 3rd parity & $4.10 \pm 0.79$ \\
\hline \multirow[t]{3}{*}{ SNP g.2425 C>G } & $\mathrm{P}=0.2226$ & $\mathrm{CC}$ & $3.27 \pm 0.44$ \\
\hline & & CG & $2.10 \pm 0.21$ \\
\hline & & GG & $1.76 \pm 0.13$ \\
\hline \multirow[t]{3}{*}{ SNP g.2436 A>G } & $\mathrm{P}=0.3447$ & AA & $3.22 \pm 0.48$ \\
\hline & & $\mathrm{AG}$ & $2.66 \pm 0.27$ \\
\hline & & GG & $1.76 \pm 0.14$ \\
\hline \multirow[t]{3}{*}{ SNP g.2459 G>A } & $\mathrm{P}=0.0027$ & $\mathrm{AA}$ & $4.01 \pm 0.96^{\mathrm{a}}$ \\
\hline & & GA & $3.89 \pm 0.68^{\mathrm{ab}}$ \\
\hline & & GG & $1.65 \pm 0.11^{\mathrm{b}}$ \\
\hline
\end{tabular}

Values with different superscripts in the same column differ significantly at $\mathrm{P}<0.05$

$\mathrm{KC}$ : Kacang goats; KJ : Kejobong goats; SD : Senduro goats

tem. The utilization of pregnant mare serum gonadotropin (PMSG) and progestagen sponge for estrus synchronization has resulted a satisfactory outcome. Internal appliances conceiving different kind of progestagen, implanted in female reproduction tract during 12-14 days were used widely (Bitaraf et al., 2007).

The intravaginal sponges were implanted for 14 days in the present research. The long term progestagen intravaginal treatment $(12-14$ days) gave better result than short term (5-7 days) but not differ significantly, whether on estrus intensity, estrus response, onset of estrus, concentration of progesterone serum at 21 days after artificial insemination (AI), length of estrus, gestation period, kidding and fecundity rate showed a different significantly (Ngangi et al., 2002; Kor et al., 2011). On the other hand, intravaginal progestagen sponge used in estrus synchronization on ewes could improve ovulation time and estrus expression, contrary it might shorten duration of estrus (Mahmoud and Senosy, 2019).

The basal concentration of progesterone hormone is reached six hours after the sponge taken out from female reproduction tract (Ngangi et al., 2002). The first three observations (0, 3 and 6 hours) were in luteal phase while other observations ( 9 and 12 hours) were in the earlier follicular phase. This might explain that the FSH plasma level increase slightly during the collection time (Table 5). In sheep, KISS1 gene expression in the sheep preoptic area (POA) is greater just previous to the late follicular phase GnRH/LH surge than luteal phase (Smith et al., 2013). For future research, longer observation time is needed to evaluate the significant result of FSH plasma level.

KISS1 gene produces kisspeptin (Kp). These peptides were performed through their receptor, G-protein-coupled receptor (GPR54). Kp has been rised as important regulators of neurons that remain in the basal forebrain and yield gonadotropin releasing hormone $(\mathrm{GnRH})$. Cells in the upstream of GnRH neurons synthesized KISS1 functionally (Knoll et al., 2013). KISS1 gene stimulates GnRH neuron activity, gene expression and the release was regulated by circulating gonadal hormones (Smith, 2013). Kp has been known as key neuroendocrine gatekeeper of reproduction and maintenance of adult reproduction recently (Millar et al., 2010). Sequences of 
KISS1 gene have revealed a polymorphism related to reproductive traits. KISS1 gene might be a significant candidate gene on reproductive traits in goats (Cao et al., 2010; An et al., 2013; ElTarabany et al., 2017; Sahoo et al., 2019).

$\mathrm{Kp}$ arranges the construction of preantal follicles negatively by leading the production of anti mullerian hormone (AMH) and degrade the sensitivity to FSH through preventing the induction of FSHR expression via sympathetic activators, thus lowering the recruitment of primary follicles (Panidis et al., 2006; Cao et al., 2019). The sympathetic nerve activity might adjust the intra ovarian $\mathrm{Kp}$ system and the peptides were needed for appropriate coordination between ovarian function both from neural or ovarian origin (Zheng et al., 2018). Furthermore, the serum levels of $\mathrm{Kp}$ are in contrary correlation with FSH, but have a positive correlation with testosterone, LH and dehydroepiandrosterone (DHEA) (Gorkem et al., 2018).

As mentioned before, fourteen haplotypes were obtained in current research. The gene flow, bottleneck and drift events, the distribution of nucleotide polymorphisms could be formed by demographic history of breed (Nordborg and Tavare, 2002), therefore estimating haplotype variations is very informative to appraise the effects of the migrations, selection or admixture in goat populations (Criscione et al., 2019)

The statistical analysis showed that haplotype affected FSH level significantly (Table 4). The CAATGCGCAACGCT haplotype (H9) goats had superior FSH plasma level compare to other haplotypes. The preliminary experiment revealed that CAATGCGCAACGCT haplotype (H9) of KISS1 gene also had high LS $\left(3 \pm 0^{b}\right)$. Moreover, the rest haplotype denoted a vary LS, not in linier with the FSH plasma level. This condition might be caused by the different goat breeds used to form the haplotype analysis. Nackley et al. (2006) suggested the significance of haplotypes over SNPs for genetic variations analysis. In agreement with this result, other researches using IGF1 bond with IGF1 receptors (IGF1R) and IGF1R haplotypes are correlated with puberty age in Brahman heifers (Fortes et al., 2013); the haplotypes of FSHB3-c had a superior effect for the semen quality (Nikbin et al., 2018); the casein complex haplotypes correlated with milk quality traits (Inostroza et al., 2020). These phenotypes were related to reproductive traits. To date, there is no published journal concerning the haplotype effect to FSH plasma lev- el. Therefore, our inference should be verified with further study.

Table 5 shows the data of FSH based on goat breeds, sample collection time, litter size, parity and genotypes. The discrepancies between breeds are significant, $\mathrm{KC}$ and $\mathrm{KJ}$ have a higher FSH concentration than SD. $\mathrm{KC}$ and $\mathrm{KJ}$ goats were collected from Grobogan and Purbalingga regency which represented lowland area $(0-200$ mMSL), further SD goats was collected from Lumajang regency which reflected high land (500 mMSL). In accordance, a breed type has a significant effect to fresh and post-thaw semen traits (Nikbin et al., 2018). Both long term artificial and natural selection enforced by animal husbandry and environmental change resulted different goats breeds in China. The multigenic traits such as prominent cold and disease resistance, strong rough fodder resistance, adaptiveness to stressful environment and high prolificacy reflects distinct natural gene pool (Liu et al., 2019).

Further, the present investigation did not find any correlation between parity and FSH plasma level (table 5). This finding is in accordance in Damascus and Zaribi goats. The TT genotype at T121A in the intron 1 of KISS1 gene had significant higher LS than TA genotype. Moreover, the difference on estradiol ${ }_{17 \beta}$ and progesterone level caused by parity is not significant (El-Tarabany et al., 2017).

The data from our previous research found that there are three obtrusive novel single nucleotide polymorphisms (SNPs) correlated with reproductive traits in three Indonesian native goat breeds (unpublished data). The SNPs are g. $2425 \mathrm{C}>\mathrm{G}$, g. $2436 \mathrm{~A}>\mathrm{G}$ and at g. $2459 \mathrm{G}>\mathrm{A}$. The previous research found a SNP in FSHB gene promoter region within one of the conserved hormone-response elements (HREs) were associated with divergent in serum FSH level in men (Grigorova et al., 2008). Herewith we report for the first time polymorphisms of KISS1 gene in goats indicating a significant correlation with FSH level (Table 5).

The recent research showed that goat breed influences the FSH level significantly, wherein SD goat have lower FSH plasma level. This finding is in accordance with previous research. Another study in human found that higher body mass index (BMI) had lower kisspeptin significantly. Metastin/kisspeptin levels were correlated with all indices of insulin resistance significantly and reversely, thus it can be concluded 
that a significant decrease in plasma metastin level is correlated with insulin resistance (Panidis et al., 2006; Chen et al., 2010). The LH levels were correlated with plasma metastin levels positively. In fact, average body weight for $\mathrm{KC}, \mathrm{KJ}$ and SD goats are $24.7 \mathrm{~kg}, 27.87 \mathrm{~kg}$ and $48.50 \mathrm{~kg}$ (Batubara et al., 2006; Sodiq and Haryanto, 2007; Ministry of Agriculture, 2014).

The mechanism of major decrease in KISS1 gene expression could lead a compensatory increase in the expression of its receptor (GPR54), causing a circumstance of sensitization to kisspeptin effects. Therefore, an enhancement of $\mathrm{LH}$ responses to Kp suggesting that substitution of endogenous KISS1 levels is adequate to activate GnRH-LH axis fully in spite of prejudicial metabolic conditions (Castellano et al., 2005).

Adipose is a necessary endocrine tissue that influence reproduction through leptin primarily (Kawwass et al., 2015; Symonds et al., 2016). Leptin acts through the GPR54 which is found on kisspeptin neurons in hypothalamus (TenaSempere, 2006 ${ }^{\mathrm{a}}$; Tena-Sempere, 2006 $)$. Kisspeptin binds to $\mathrm{GnRH}$ neurons and provokes GnRH release (Roseweir and Millar, 2009). The leptin-kisspeptin-GnRH neuron pathway presents the endocrine argument for the critical body weight hypothesis, which body weight relate to puberty in female (Keisler et al., 1999). Thus, earlier result suggest that higher BMI caused lower LH surge, in turned FSH plasma level also decrease, but this finding needed further research.

Nowadays, the effect of Kp on FSH secretion is less information. The response of KISS1 to FSH release emerge less sensitive than LH considerably. The pathway organized centrally through modulation GnRH system, moreover it conducted independently with other neuroendocrine regulators of gonadotropic axis such as excitatory amino acids (EEAs), nitric oxide (NO) and leptin (Navarro, 2005). The positive reaction of leptin in GnRH is mediated by proopiomelanocortins (POMC, precursor of $\alpha$ $\mathrm{MSH}$ ), galanin-like peptide (GALP) and kisspeptin neuropeptides (Gottsch et al., 2004; Crown et al., 2007; Quennell et al., 2009). Kp is detected in the growing follicles at theca cells and begins to arise in the basal cells of granular layer in rodent and human (Castellano et al., 2006). FSH is not under control entirely by GnRH (Charlton, 1983; Phillips, 2005), but the major stimulus for FSH is GnRH (Mason et al., 1986).

In our prior study, the obtrusive genotype of
KISS1 gene intron 1 that correlated with higher LS, particularly average LS at the first and third parity in Indonesian native goat breeds which are $\mathrm{CC}$ genotype at g.2425C $>\mathrm{G}$, AA genotype at g. $2436 \mathrm{~A}>\mathrm{G}$ and $\mathrm{GA}$ genotype at g.2459G $>\mathrm{A}$ (unpublished data). The data above (Table 5) showed that the genotypes at g. $2425 \mathrm{C}>\mathrm{G}$ and g.2436A $>\mathrm{G}$ have unsignificant $\mathrm{FSH}$ plasma level $(\mathrm{P}=0.22$ and $\mathrm{P}=0.34$ respectively). On the other hand, the AA genotype at g.2459G $>$ A has a superior FSH level than GG genotype (Fig.3).

Preliminary study revealed that $\mathrm{CC}$ genotype at g.2425C $>$ G, AA genotype at g.2436A $>$ G and GA genotype at g.2459G $>$ A had significant greater litter size $(2.58 \pm 0.14,2.58 \pm 0.14$ and $3.0 \pm 0.18$ respectively). Furthermore, neither CC genotype at g. $2425 \mathrm{C}>\mathrm{G}$ nor the AA genotype at g.2436A $>\mathrm{G}$ have higher FSH levels eventhough not differing significantly. On the other hand, GA genotype at g. $2459 \mathrm{G}>$ A reveals a higher LS $(3.0 \pm 0.18)$ than AA genotype which has a lower LS (2.0 \pm 0.21$)$. However both genotypes have the same FSH plasma level. Thus, it can be concluded that GA genotype at g.2459G $>A$ is the most prominent genotype correlated with reproductive traits in Indonesian native goats.

\section{CONCLUSION}

The phylogenetic tree reveals a high closeness between Indonesian and Chinese goat breeds indicating the same function and tightness along the evolutionary timescale. Capra hircus and Ovis aries were also found in the same clade with Indonesian goat breed represent a significant role of KISS1 gene in reproductive traits in a variety of species.

The FSH level was influenced by breed, LS, and haplotype. The superior haplotype and genotype of KISS1 gene is CAATGCGCAACGCT haplotype and GA genotype at g.2459G $>$ A that correlated with high LS and FSH level. These aspects could be considered in further breeding selection program for economically significant reproductive traits in goats.

\section{ACKNOWLEDGEMENTS}

This research was funded by Directorate General of Strengthening Research and Development, Ministry of Research and Technology/ National Agency for Research and Innovation, Republic of Indonesia with contract No. 187-47/ UN7.6.1/PP/2021 dated March 8, 2021 in part 
was supported by Ministry of Agriculture, Republic of Indonesia.

\section{REFERENCES}

Amills, M, J. Capote and G. Tosser-Klopp. 2017. Goat domestication and breeding: a jigsaw of historical, biological and molecular data with missing pieces. Animal Genetics. 48:631-644.

An, X.P., T. Ma, J.X. Hou, F. Fang, P. Han, Y. Yan, H. Zhao, Y.X. Song, J. Wang and B. Cao. 2013. Association analysis between variants in KISS1 gene and litter size in goats. BMC Genetics. 14:63-68.

Aziz, M. A. 2010. Present status of the world goat populations and their productivity. Lohmann Inform. 45(2):42-52.

Barker, J.S.F., S.G. Tan, S.S. Moore, T.K. Mukherjee, L.J. Matheson and O.S. Selvaraj. 2001. Genetic variation within and relationships among populations of Asian goats (Capra hircus). J Anim Breed Genet. 118:213-233.

Batubara, A, M. Doloksaribu and B. Tiesnamurti. 2006. Potential diversity of Indonesian local goat genetic resources. National Workshop on Management and Protection of Genetic Resources in Indonesia: Economic Benefits for Realizing National Resilience. Bogor, 20th December 2006. Indonesian Agency for Agricultural Research and Development. 206-214.

Bitaraf, A., M.J. Zamiri, M. Kafi and J. Izadifard, 2007. Efficacy of CIDR, fluogestone acetate sponges and cloprostenol for estrous synchronization of Nadooshani goats during the breeding season. Iran J. Vet. Res., 9: 17-22.

Cao, G.L., M.X. Chu, L. Fan, R. Di, T. Feng and N. Li. 2010. Analysis on DNA sequence of KiSS-1 gene and its association with litter size in goats. Mol Biol Rep.37:3921-3929.

Cao, Y., Z. Li, W. Jiang, Y. Ling and H. Kuang. 2019. Reproductive functions of Kisspeptin/ KISS1R Systems in the Periphery. Reprod. Biol. Endocrinol. 17(65) : 1-9.

Castellano, J.M., V. M. Navarro, R. FernándezFernández, R. Nogueiras, S. Tovar, J. Roa, M. J. Vazquez, E. Vigo, F. F. Casanueva, E. Aguilar, L. Pinilla, C. Dieguez and M. Tena -Sempere. 2005. Changes in hypothalamic KiSS-1 system and restoration of pubertal activation of the reproductive axis by kis- speptin in under nutrition. Endocrinology. 146(9):3917-3925.

Castellano, J.M., M. Gaytan, J. Roa, E. Vigo, V.M. Navarro, C. Bellido, C. Dieguez, E. Aguilar, J. E. Sánchez-Criado, A. Pellicer, L. Pinilla, F. Gaytan and M. Tena-Sempere. 2006. Expression of KiSS-1 in rat ovary: putative local regulator of ovulation? Endocrinology. 147(10):4852-62.

Charlton, H.M, D.M. Halpin, C. Iddon, R. Rosie, G. Levy, I.F. McDowell, A. Megson, J. F. Morris, A. Bramwell, A. Speight, B. J. Ward, J. Broadhead, G. Davey-Smith and G. Fink. 1983. The effects of daily administration of single and multiple injections of gonadotropin-releasing hormone on pituitary and gonadal function in the hypogonadal (HPG) mouse. Endocrinology. 113:53544.

Chen, X., Y. Mo, Y. Li and D. Yang. 2010. Increased plasma metastin levels in adolescent women with polycystic ovary syndrome. Eur. J. Obstet. Gynecol. Reprod Biol.149:72-6.

Ciptadi, G., M. N. Ihsan, A. Budiarto, M. Mudawamah, A. I. Putri, and M. N. A. Naufal. 2019. Reproductive characters of Senduro goat at Lumajang district East Java. Journal of Physics. 1146:1-4.

Criscione, A., S. Tumino, M. Avondo, D. Marletta and S. Bordonaro. 2019. Casein haplotype diversity in seven dairy goat breeds. Arch. Anim. Breed., 62, 447-454.

Crown, A., D.K. Clifton and R.A. Steiner. 2007. Neuropeptide signaling in the integration of metabolism and reproduction. Neuroendocrinology. 86:175-182.

El-Tarabany MS, Zagloola AW, El-Tarabany AA, Awad A. 2017. Association analysis of polymorphism in KiSS1 gene with reproductive traits in goats. Anim Reprod Sci.180:92-99.

Fortes, M.R, Y. Li, E. Collis, Y. Zhang and R.J. Hawken. 2013. The IGF1 pathway genes and their association with age of puberty in cattle. Anim Genet. 44:91-95.

Gorkem, U., C. Togrul, E. Arslan, A. S. Oruc and N. B. Duman. 2018. Is there a role for kisspeptin in pathogenesis of polycystic ovary syndrome? Gynecol. Endocrinol. 34 (2):157-160.

Gottsch, M.L., D.K. Clifton and R.A. Steiner. 2004. Galanin-like peptide as a link in the integration of metabolism and reproduction. 
Trends. Endocrinol. Metab. 15:215-221.

Grigorova, M., M. Punab, K. Ausmees and M. Laan. 2008. FSHB promoter polymorphism within evolutionary conserved element is associated with serum FSH level in men. Human Reproduction. 23(9):2160-2166.

Guerrero, A., J.A. Abecia, C. Sañudo. 2020. Goats (Capra) : From ancient to modern. Intech Open Ltd. London. UK.

Inostroza, M.G.P., F.J.N. González, V. Landi, J.M.L. Jurado, J.V.D. Bermejo, J.F. Álvarez and M. A. M. Martínez. 2020. Bayesian analysis of the association between casein complex haplotype variants and milk yield, composition, and curve shape parameters in Murciano-Granadina goats. Animals. 10:1845-63.

Kawwass, J.F., R. Summer and C.B. Kallen. 2015. Direct effects of leptin and adiponection on peripheral reproductive tissues; a critical review. Mol. Human Reprod. 21:617-632.

Keisler, D.H., J.A. Daniel and C.D. Morrison. 1999. The role of leptin in nutritional status and reproductive function. J. Repord. Fert. (Suppl). 54:425-435.

Knoll, J.G., C.M. Clay, G.J. Bouma, T.R. Henion, G.A. Schwarting, R.P. Millar and S.A. Tobet. 2013. Developmental profile and sexually dimorphic expression of KiSS1 and KiSS1R in the fetal mouse brain front. Endocrinology. 140(4):1-13.

Kor, N.M., N. Ziaei and E.E. Pour. 2011. Comparison of reproductive performance in Raieni goats following different estrous synchronization methods and subsequent ECG treatment during the natural breeding season. Global Veterinaria. 7 (6): 618-624.

Lestari, D.A., E. Purbowati, S. Sutopo and E. Kurnianto. 2018. Phylogenetical relationships between Kejobong goat and other goats Based on Mt-DNA D-loop sequence analysis. Veterinary World. 11:1196-1202.

Liu, G., Q. Zhao, J. Lu, F. Sun, X. Han, J. Zhao, H. Feng, K. Wang and C. Liu. 2019. Insights into the genetic diversity of indigenous goats and their conservation priorities. Asian Australas. J. Anim Sci. 32(10):15011510.

Mahdavi, M. and G.R. Dashab. 2017. An evolutionary and phylogenetic study of the BMP15 gene. IJAS. 7(2) : 197-209.

Mahmoud, G.B. and W. Senosy. 2019. Effect of synchronizing estrus with intravaginal pro- gestagen sponges or prostaglandin $\mathrm{F} 2 \alpha$ on estrus behavior, ovarian structures, estradiol $-17 \beta$ and progesterone levels of Ossimi ewes under subtropics. Egyptian J. Sheep Goat Sci. 14(1):53-60.

Mandal, M., C. Mishra, S.K. Dash, L.L. Swain, S. K. Pradhan and G. Nayak. 2020. Identification and futuristic role of novel polymorphism of caprine PrP gene. Anim. Biotechnol. DOI: 10.1080/10495398.2020.1765789.

Mason, A.J., J.S. Hayflick, R.T. Zoeller, W.S. Young, H.S. Phillips, K. Nikolics and P.H. Seeburg. 1986. A deletion truncating the gonadotropin-releasing hormone gene is responsible for hypogonadism in the HPG mouse. Science. 234:1366-71.

Millar, R.P, A. K. Roseweir, J. A. Tello, R. A. Anderson, J. T. George, K. Morgan and A. J. Pawson. 2010. Kisspeptin antagonists: unraveling the role of kisspeptin inreproductive. Brain Research. 1364:81-89.

Ministry of Agriculture of Indonesia. 2014. Decree of Senduro goat as a native goat in Indonesia Num. 1055/Kpts/ SR.120/10/2014. Jakarta.

Ministry of Agriculture of Indonesisa. 2020. The Statistic Book on Livestock and Animal Health Services. Directorate General of Livestock and Animal Health Services. Jakarta.

Nackley, A.G., S.A. Shabalina, I.E. Tchivileva and K. Satterfield. 2006. Human catechol-O -methyltransferase haplotypes modulate protein expression by altering mRNA secondary structure. Science. 314:1930-1933.

Nagamalleswari, Y., M.P. Iyyangar, S. Gopinath and K.B.P. Raghavender. 2004. Biometrical relationship of ovaries and pituitary during prepubertal period in goat (Capra hircus). Indian J Anim Sci.74:256-8.

Ngangi, L.R., M.R. Toelihere, B. Purwantara and K. Sutama. 2002. Efektivitas lama pemberian progesteron intravaginal dan waktu inseminasi terhadap penampilan reproduksi kambing Peranakan Etawah. Institut Pertanian Bogor. Doctoral Theses.

Navarro, V.M., J,M, Castellano, R. FernandezFernandez, S. Tovar, J. Roa, A. Mayen, M.L. Barreiro, F.F. Casanueva, E. Aguilar, C. Dieguez, L. Pinilla and M. TenaSempere . 2005. Effects of KiSS-1 peptide, the natural ligand of GPR54, on follicle stimulating hormone secretion in the rat. Endocrinol.146(4):1689-1697. 
Nikbin, S., J. M. Panandam, H. Yaakub and M. Murugaiyah. 2018. Association of novel SNPs in gonadotropin genes with sperm quality traits of Boer goats and Boer crosses. J. Appl. Anim. Res. 46:459-466.

Nordborg, M. and S. Tavaré. 2002. Linkage disequilibrium: what history has to tell us. Trends in Genetics. 18(2):83-90.

Panidis, D., D. Rousso, G. Koliakos, A. Kourtis, I. Katsikis, D. Farmakiotis, E. Votsi and E. Diamanti-Kandarakis. 2006. Plasma metastin levels are negatively correlated with insulin resistance and free androgens in with polycystic ovary syndrome. Fertil Steril. 85:1778-83.

Phillips, D.J. 2005. Activins, inhibins and follistatins in the large domestic species. Domest. Anim. Endocrinol. 28(1):1-16.

Pinilla, L., E. Aguilar, C. Dieguez, R. P. Millar and Tena-Sempere. 2012. Kisspeptins and reproduction: physiological roles and regulatory mechanisms. Physiol. Rev. 92:12351316.

Psifidi, A., C. I. Dovas, G. Bramis, T. Lazou, C. L. Russel, G. Arsenos and G. Banos. 2015. Comparison of eleven methods for genomic DNA extraction suitable for large-scale whole-genome genotyping and long-term DNA banking using blood samples. Plos One. $\quad$ https://doi.org/10.1371/ journal.pone. 0115960

Quennell, J.H., A.C. Mulligan, A. Tups, X. Liu, S.J. Phipps, C.J. Kemp, A.E. Herbison, D.R. Grattan and G.M. Anderson. 2009. Leptin indirectly regulates gonadotropin releasing hormone neuronal function. Endocrinol. 150:2805-2812.

Ropiquet, A. and A. Hassanin. 2006. Hybrid origin of the Pliocene ancestor of wild goats. Mol. Phylogen. Evol. 41:395-404.

Roseweir, A.K. and R.P. Millar RP. 2009. The role of kisspeptin in the control of gonadotrophin secretion. Hum. Reprod. Update. 15:203-212.
Sahoo, S. S., C. Mishra, R. Kaushik, P. K. Rout, M. K. Singh, S. Bhusan dan M. S. Dige. 2019. Association of a SNP in KISS 1 gene with reproductive traits in goats. Biol. Rhythm Res. 23:1-12.

Smith, J.T. 2013. Sex steroid regulation of kisspeptin circuits. Adv. Exp. Med. Biol. 784:275-95.

Sodiq, A. dan B. Haryanto. 2007. Non-genetic factor influence on doe productivity performance of local Kejobong goat under village production system. J. Anim. Prod. 9 (3) : 123-128.

Stella, A., E.L. Nicolazzi, C.P. Van Tassell, M.F. Rothschild, L. Colli, et al., 2018. AdaptMap: exploring goat diversity and adaptation. Genet. Sel. Evol. 50 (61):1-7.

Symonds, M.E., N. Dellschaft, M. Pope, M. Birtwistle, R. Alagal, D. Keisler and H. Budge. 2016. Developmental programming, adiposity, and reproduction in ruminants. Theriogenology. 86:120-129.

Tena-Sempere, M. $2006^{\mathrm{a}}$. The roles of kisspeptin and $\mathrm{G}$ protein-coupled receptor-54 in pubertal development. Curr. Opin. Pediat. 18:442447.

Tena-Sempere, M. 2006 ${ }^{\mathrm{b}}$. KiSS-1 and reproduction: Focus on its role in the metabolic regulation of fertility. Neuroendocrinol. 83:275281.

Wang, X., J. Liu, G. Zhou, J. Guo, H. Yan, Y. Niu, et al., 2016. Whole-genome sequencing of eight goat populations for the detection of selection signatures underlying production and adaptive traits. Nature. 6:38932.

Wildeus, S. 2000. Current concepts in synchronization of estrus: Sheep and goats. J. Anim. Sci. 77:1-14

Zheng, J., S.H.A. Raza, X.D. Zi and J.Y. Lu. 2018. Comparing KISS1 and GPR54 genes between the two breeds of goats with low and high prolificacy. Gen Mol. Res. 17(4):1 -11 . 